\title{
The Relationship Between Economic Growth and Foreign Aid: The Case of Afghanistan
}

\section{Ekonomik Büyüme ile Dış Yardımlar Arasındaki İlişki: Afganistan Örneği}

\author{
Muhammad Akbar FARAHMAND ${ }^{1}$ [
}

\begin{abstract}
One of the main goals of foreign aid is to contribute to underdeveloped and developing countries' economic growth and accelerate their growth. Foreign aid has been provided to Afghanistan by developed and developing countries for many years. Especially after 2001, the flow of foreign aid to Afghanistan started and continues until today. Despite billions of foreign aids provided, the country's economy still faces lowincome levels, high poverty, and unemployment rates. In this study, the relationship between official development assistance and economic growth was analyzed using the time series method for Afghanistan between 1986 and 2018. For this purpose, ADF and Phillips-Perron (PP) unit root tests were performed to stabilize the series used. Then, after the lag length was determined, the Johansen cointegration test was conducted to test whether these two variables move together in the long run. As a result of the test, a cointegration relationship between variables has been proved. The Granger causality test based on the error correction model was conducted to investigate the causality relationship between these two variables. As a result, a one-way causality relationship from the received official development assistance to economic growth was determined. Finally, the results of variance decomposition support the result of the Granger causality test.
\end{abstract}

Keywords: Foreign aid, Economic growth, Cointegration analysis, Causality analysis

Jel Code: C1, C32, F35, O4

öz

Dış yardımların temel hedeflerinden biri, az gelişmiş ve gelişmekte olan ülkelerin ekonomik büyümelerine katkı sağlaması ve büyümelerini hızlandırmasıdır. Afganistan'a uzun yıllardır gelişmiş ve gelişmekte olan
${ }^{1} \mathrm{Ph} . \mathrm{D}$. student, Istanbul University, Institute of Social Sciences, Lecturer at Mawlana Jalaluddin Mohammad Balkhi University, Afghanistan.

ORCID: M.A.F. 0000-0002-5457-9105

\section{Corresponding author/Sorumlu yazar:}

Muhammad Akbar FARAHMAND,

Mawlana Jalaluddin Mohammad Balkhi

University, Afghanistan

E-mail/E-posta:

akbarfarahmand279@yahoo.com

Submitted/Başvuru: 23.02.2021

Revision Requested/Revizyon Talebi:

24.03.2021

Last Revision Received/Son Revizyon: 31.03.2021

Accepted/Kabul: 06.04.2021

Citation/Atıf: Farahmand, M.A. (2021). The relationship between economic growth and foreign aid: The case of Afghanistan. Iktisat Politikası Araştırmaları Dergisi - Journal of Economic Policy Researches, 8(2), 141-154. https://doi.org/10.26650/JEPR885246 
ülkeler tarafından dış yardımlar yapılmaktadır. Özellikle 2001 yılından sonra Afganistan'a dış yardım akışı başlamış ve bu dış yardım hala devam etmektedir. Milyarca dış yardım sağlanmasın rağmen, hala ülke ekonomisi düşük gelir seviyesi, yüksek yoksulluk ve işsizlik oranı ile karşı karşıyadır. Bu çalışmada, alınan resmi kalkınma yardımı ile ekonomik büyüme arasındaki ilişki, 1986-2018 yılları arasındaki dönemde Afganistan için zaman serisi yöntemi kullanılarak incelenmiştir. Bu amaçla, ilk olarak kullanılan serilerin durağanlaştırılması için ADF ve Phillips-Perron (PP) birim kök testleri yapılmıştır. Daha sonra gecikme uzunluğunu belirlenmesinin ardından bu iki değişkenin uzun dönemde birlikte hareket edip etmediğini sınamak için Johansen eşbütünleşme testi yapılmıştır. Yapılan test sonucunda, değişkenler arasında bir eşbütünleşme ilişkisi ispat edilmiştir. Ayrıca bu iki değişken arasındaki nedensellik ilişkisini araştırmak için hata düzeltme modeline dayalı Granger nedensellik testi yapılmıştır. Sonuç olarak, alınmış resmi kalkınma yardımlardan ekonomik büyümeye tek yönlü nedensellik ilişkinin varlığı tespit edilmiştir. Son olarak yapılan varyans ayrıştırma sonuçları da Granger nedensellik testinin sonucunu desteklemektedir.

Keywords: Dış yardım, Ekonomik büyüme, Eşbütünleşme analizi, Nedensellik analizi

Jel Code: C1, C32, F35, O4

\section{Introduction}

Contribution, donations, loans, and other positive effects of developed countries to underdeveloped or developing countries for various purposes constitute foreign aid (Koç, 2016). Foreign aid has been an essential resource for accelerating developing and less developed countries' economic growth throughout history. Therefore, foreign aid has the potential to contribute to different economic areas of countries, such as social and economic infrastructures, production and service sectors, education, agriculture, rural development, and food security (Hee Yiew \& Lau, 2018). These aids are given to underdeveloped and developing countries free of charge or in the form of loans at low interest rates by developed countries or international organizations. As a foreign direct investment, foreign aid is beneficial for developing countries and causes increased investment and decreased foreign borrowing. At the same time, foreign aid causes an increase in public consumption expenditures (Hussen \& Lee, 2018).

Researchers have discussed the effects of foreign aid on economic growth for many years. However, there is no consensus on foreign aid's effects on economic growth (Görgülü, 2016). There are two views in the economics literature about the impact that foreign aid can have on economic growth. According to the first view, aid from abroad will contribute positively to developing and less developed countries' economic growth and development. Because in developing and underdeveloped countries, foreign aid contributes to macro and microeconomic factors and closes the foreign exchange deficit. On the other hand, according to the second view, foreign aid causes deterioration of the internal income distribution in recipient countries and interferes with the country's economic and political policies. Thus, foreign aid will have adverse effects on recipient countries' economic growth and development (Hatemi-j \& İrandoust, 2005). 
Since the establishment of the World Bank and the United Nations (UN), economic growth and development have been important goals of international countries. Foreign aid started to flow from developed countries to underdeveloped and developing countries to accelerate these countries' economic growth and development. The flow of foreign aid to Afghanistan started in 1950, and these aids continue until today. The government of Afghanistan increased its economic growth with the foreign aid received after the Second World War. However, the economic growth of the country was interrupted due to the conflicts in the country between 1979-2001. As a result of these conflicts, besides the destruction of the economic infrastructure worth 240 billion dollars, two million people lost their lives, one million people became disabled, and about three million people migrated to foreign countries as refugees. Also, these conflicts ended the modernization and industrialization process that started after independence in the country. Therefore, despite the flow of foreign aid, an average negative growth rate of $2.54 \%$ was recorded in the country's economic growth (Nasery, 2014). By 2001, there was no financing fund available to get the economy back on track in Afghanistan. In 2001, the structuring process in the country started. This structuring process has been primarily financed by foreign aid. Therefore, the flow of foreign aid made a significant contribution to the growth of the economy between 2003 and 2012. In the country's economy, an average growth rate of 9\% was recorded between 2003-2012. However, the economic growth rate has slowed down due to the decrease in foreign aid since 2012 and the country's increasing instability (World Bank, 2017).

In terms of natural resources, Afghanistan is one of the richest countries in the world. Despite that there are around three trillion dollars of mineral deposits in Afghanistan, its economy is still dependent on foreign aid because Afghanistan cannot fully utilize its natural resources to reduce poverty, unemployment, and external dependency and increase its per capita income ( Noorani \& Brouckere, 2016).

In the first part of the study, the effects of official development assistance to Afghanistan on the economic development of the country are mentioned. Studies that indicate the relationship between foreign aid and economic growth are mentioned in the second part. Finally, the relationship between official development assistance and economic growth for Afghanistan was analyzed using the time series method.

\section{The Impact of Foreign Aids on Economic Development of Afghanistan}

The history of foreign aid to Afghanistan dates back to ancient times. For the first time in 1857, during the British rule in South Asia, financial aid was received from the East India company. However, after the Second World War, Afghanistan, located in Central Asia, 
started to receive foreign aid from the World Bank, the Asian Development Bank, the United States (USA), and the Soviet Union (USSR) to improve its economic growth. These aids continued at a low level until 2000 (Nasery, 2014). In Figure 1, the official development aids received by Afghanistan and the GDP of Afghanistan between 1986 and 2000 are shown.

Figure 1:Official Development Assistance and GDP Received by Afghanistan between 1986-2000

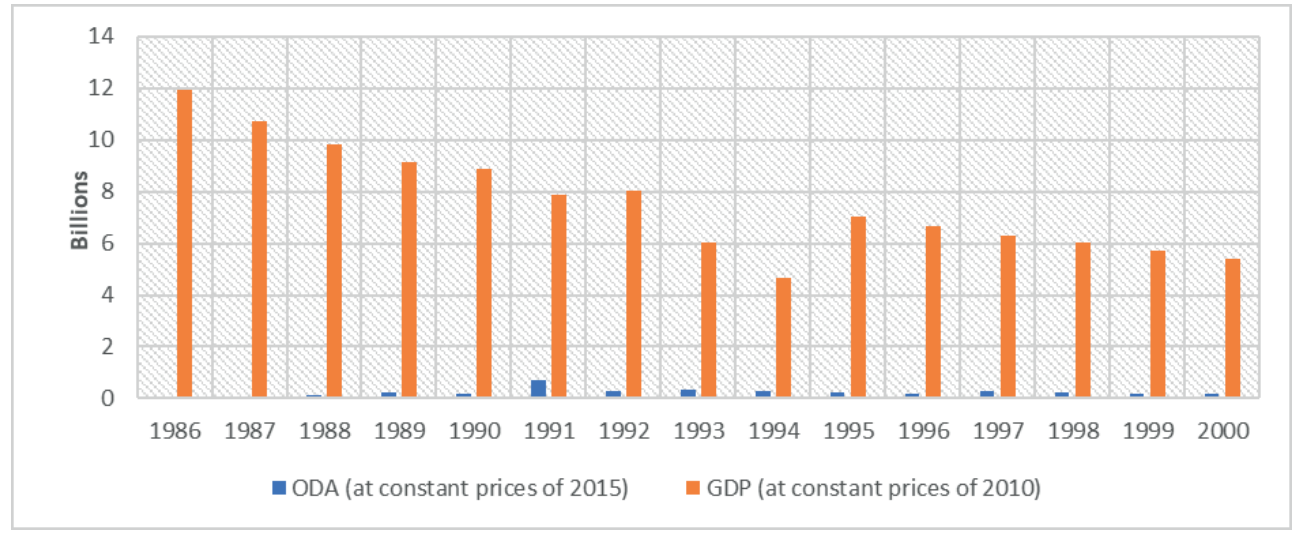

Source: World Bank database

Major conflicts took place in Afghanistan between 1979 and 2000. For this reason, its economic growth gradually decreased until 2001 despite the official development assistance. According to Figure 1, official development assistance has continued with a slight increase from 1986 until 2000. However, the rate of GDP has gradually decreased. In the period between 1979-2001, the country's economy recorded a negative growth rate of $2.54 \%$ on average. Therefore, the economic assets of the country were almost destroyed due to the conflicts between 1979-2001 (Nasery, 2014).

With the end of the Taliban era in 2001 and the establishment of a democratic government, the process of structuring the country began. However, there were no financial resources available in the country to continue this process. In 2001, foreign aid was made by other developed countries, especially the USA, to areas such as agriculture, education, and health to stimulate the economy, rebuild and expand infrastructures, increase military power, strengthen democracy (United States Congress, 2018).

In 2001, Afghanistan's basic economic policy was founded on foreign aid and foreign investment (Kabil, 2017). Almost Afghanistan's development budget has been financed mainly by international countries, especially since 2001 (IEG, 2013).

The restructuring process that started in Afghanistan in 2001 was not possible without the international coalition's strong support. This configuration process has been funded by 
countries such as the US, Britain, Canada, Czech Republic, Australia, Denmark, China, Italy, Japan, France, Finland, and Turkey (Kabil, 2017).

The World Bank has contributed to areas such as infrastructure, rural development, education, reduction of unemployment, electricity distribution and production, and increasing the quality of health and education in Afghanistan and other international countries. The World Bank provided nearly \$3 billion in aid in the specified areas between 2002 and 2017. 2.63 billion dollars of these aids were provided as grants and 436 million dollars as an interest-free loan (Kabil, 2017). Figure 2 shows the official development assistance received by Afghanistan between the years 2001-2018 and the GDP of Afghanistan.

Figure 2: Official Development Assistance and GDP Received by Afghanistan between 2001-2018

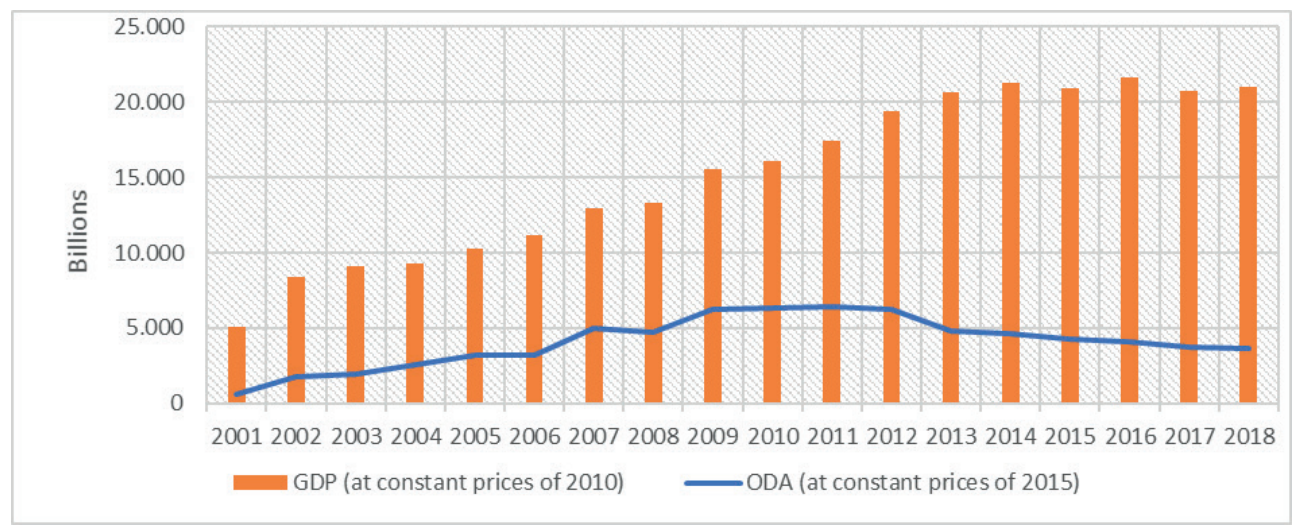

Source: World Bank database

While the GDP of Afghanistan was more than 5 billion dollars in 2001, this value increased to approximately 21 billion dollars in 2018. Official development assistance was valued at $\$ 410$ million in 2001, while it reached $\$ 3.645$ billion in 2018 . Therefore, with the increase in foreign aid, the economic growth rate started to increase. Development assistance to Afghanistan has increased gradually from 2001 until 2012. However, the reverse of this situation occurred after 2012, and development assistance continued to decrease. For the first time in the economic history of the country, an average of $9 \%$ growth was recorded between 2002-2013. Therefore, Figure 2 shows that both official development assistance and the economic growth rate increased from 2001 to 2012. However, the decrease in foreign aid after 2012 negatively affected the economic growth. While official development assistance was more than 6 billion dollars in 2012, this value decreased to 5 billion in 2013 and gradually decreased with the gradual decrease of international powers in the following 
periods. The decrease in official development assistance, decrease in investments due to the increase of internal instability, increase in drought, and return of refugees had a negative effect on the macro-economic indicators of the country after 2012. Therefore, the economic growth of the country in 2014 was $2.7 \%$, to $1.5 \%$ in 2015 , to $2.3 \%$ in 2016 ; it decreased to $2.7 \%$ in 2017 and $2.4 \%$ in 2018 (World Bank, 2018).

Billions of dollars of development assistance flowed from other countries, especially the USA, to support Afghanistan's restructuring process after 2001. However, despite the increasing economic growth with the increase in development assistance, the country's poverty rate is still $55 \%$, and the unemployment rate is $40 \%$. The lack of capacity in the Afghanistan administration has resulted in the inability to efficiently spend billions of dollars of aid and the disruption of the widespread income distribution, widespread corruption, and increased instability (Zazai, 2018). On the other hand, some of the foreign aid to Afghanistan has been spent to realize the aims of international countries, and some of the promised financial aid has not been paid (IEG, 2013).

Afghanistan's budget in 2019 was determined as 399.4 billion Afghanis. However, 47\% of this budget is financed from domestic income and approximately $50 \%$ by foreign aid (World Bank, 2019). Therefore, even if foreign aid decreases today, it still plays a vital role in the economic growth and development of the country. Foreign aid to Afghanistan will decrease more in the coming years. For this reason, the Afghanistan government focuses on extracting rich natural resources to free the country's economy from external dependence, accelerate economic growth, and reduce poverty and unemployment rates. Natural resources are the most important financial resource to save the country's economy from external dependency and accelerate economic growth (Farahamand \& Esen, 2018).

\section{Literature Review}

Economists have discussed the impact of foreign aid on economic growth for a long time. There are extensive studies in the economics literature examining the relationship between foreign aid and economic growth. However, there is no study analyzing the relationship between foreign aid to Afghanistan and economic growth. Therefore, in this section, the studies that show that the relationship between foreign aid and economic growth is positive and then that the relationship between these two variables is negative will be mentioned.

Papanek (1973), Fayissa and El-Kaissy (1999), Levy (1988), Hatemi and Irandoust (2005), Sekmen (2006), Karras (2006), Fasanya and Onakoya (2012), Siddique, Kiani, and Batool (2018) found that the relationship between foreign aid and economic growth is positive. 
Papanek (1973) investigated the impact of foreign aid on economic growth between the years 1960-1970 using panel data analysis for 51 less developed countries. As a result, Papanek stated that foreign aid had a positive effect on the economic growth of less developed countries. In another study, Fayissa and El-Kaissy (1999) explained that foreign aid positively affected the economic growth of developing countries by using modern economic growth theories between 1971-1980, 1981-1990, and 1971-1990 in 77 countries. Levy (1988) examined the impact of foreign aid on economic growth in Sub-Saharan Africa. Through the study, it was found that there is a positive relationship between foreign aid and economic growth. Hatemi and Irandoust (2005) analyzed the relationship between economic growth and foreign aid to Botswana, Ethiopia, India, Kenya, Sri Lanka, and Tanzania between 1974-1996 by using panel data analysis. They found that foreign aid had a positive and significant effect on the economic factors of each country. Sekmen (2006) examined the relationship between foreign aid and economic growth between 1960 and 2005 with the Granger causality test. The results of Sekmen's study indicated the existence of a one-way causality relationship from foreign aid to economic growth in Egypt was determined. Karras (2006) investigated the relationship between foreign aid and growth in per capita GDP for 71 developing countries receiving aid, using data from 1960-1997, with panel data analysis. Karras concluded that the impact of foreign aid on economic growth is positive, permanent, statistically significant, and large. Therefore, the increase in the flow of foreign aid in these countries positively affects economic growth and thus increases the recipient countries' economic growth. Fasanya and Onakoya (2012) empirically examined the impact of foreign aid made to Nigeria between 1970 and 2010 on economic growth. They found that foreign aid flows had a significant impact on economic growth in Nigeria. Siddique, Kian, and Batool (2018) analyzed the impact of foreign aid on economic growth between 1995 and 2013 for South and East Asian countries using panel data analysis in their study. Significant and robust results were obtained in the panel data analysis that showed foreign aid supported economic growth.

For many years, the African region, which hosts the poorest countries in the world, has been helping developed countries to develop macroeconomics. However, despite these aids, most African countries still struggle with poverty and hunger. Mallik (2008), Liew, Mohamed, and Mzee (2012), Mbah and Amassoma (2014), Tüzemen and Tüzemen (2015) that there was a negative relationship between foreign aid and economic growth in their findings. Mallik (2008) analyzed the relationship between economic growth and foreign aid provided to Nigeria, Malawi, Mali, Sierra Leone, Central African Republic, and Togo countries between 1965 and 2005 using the cointegration test. Mallik concluded in her study that the impact of long-term foreign aid on economic growth was negative for most of these countries. Liew et al. (2012) studied the impact of foreign aid on economic growth in East 
African countries between 1985 and 2010 by applying least squares, random effects, and fixed-effects models. As a result, they found a negative relationship between foreign aid and economic growth. Mbah and Amassoma (2014) analyzed using Least Squares and Johansen cointegration tests to determine the long-term linear relationship between foreign aid to Nigeria and economic growth between 1981-2012. As a result of the analysis, they found a negative relationship between foreign aid and economic growth. Between 1967-2013, with the cointegration test and error correction model, Tüzemen and Tüzemen (2015) examined the relationship between foreign aid and economic growth for Turkey. They found a nonlinear relationship between these two variables.

In summary, the research results on the relationship between foreign aid and economic growth differ according to the models, data, and the countries analyzed.

\section{Data Set and Econometric Method}

The real GDP data used in the study were taken from the Unstats database and the official development assistance (ODA) data from the World Bank database. In this study, the relationship between official development assistance and real GDP for Afghanistan between 1986 and 2018 is examined by time series analysis. For this purpose, firstly, the logarithms of the series were taken in Eviews 9 package program. ADF and Phillips-Perron (PP) unit root tests were carried out to stabilize the series used. Then, if it is found that the variables meet the same degree of stasis condition, the next step is to examine the long-term relationship between the variables. Johansen cointegration test was conducted to test whether these two variables act together in the long run (Gokmenoglu, Amin, and Taspinar, 2015). In addition, the Granger causality test based on the error correction model was performed to investigate the causality relationship between these two variables. Finally, variance decomposition analysis was performed to look at the effects of the series on each other.

When time series is used in econometric analysis, the series must first be stationary. Because when working with non-stationary series, although there is no real relationship between the series, it can be met with the result that there is a real relationship. Therefore, when non-stationary series are used in the analysis, this may lead to spurious regression (Ata \& Eren 2018). In the study, since both variables have an increasing trend after a certain time, fixed and trend ADF and PP unit root tests are performed. 
Table 1: ADF and PP Unit Root Test of LOGDP and LOODA

\begin{tabular}{|c|c|c|c|c|c|c|}
\hline Variables & & & T-statistics & Prob-value & T-statistics & Prob-value \\
\hline \multirow{2}{*}{ LOGDP } & In level & $\begin{array}{c}\text { Trend and } \\
\text { intercept }\end{array}$ & -0.282852 & 0.9168 & -2.383886 & 0.3804 \\
\hline & $\begin{array}{c}\text { First } \\
\text { difference }\end{array}$ & $\begin{array}{l}\text { Trend and } \\
\text { intercept }\end{array}$ & -5.222846 & 0.0002 & -5.556542 & 0.0004 \\
\hline \multirow{2}{*}{ LOODA } & In level & $\begin{array}{l}\text { Trend and } \\
\text { intercept }\end{array}$ & -1.519215 & 0.8009 & -4.103817 & 0.1039 \\
\hline & $\begin{array}{c}\text { First } \\
\text { difference }\end{array}$ & $\begin{array}{c}\text { Trend and } \\
\text { intercept }\end{array}$ & -7.973697 & 0.0000 & -7.8225 & 0.0000 \\
\hline
\end{tabular}

Note: The asterisks *,**,*** in the table shows $1 \%, 5 \%$ and $10 \%$ significance levels, respectively.

As a result of the ADF and PP unit root tests performed in Table 1, it is seen from the t-statistics and p-values that the LOGDP and LOODA variables are not stable in the level values. Simply put, if the p-value is greater than $5 \%$, the null hypothesis cannot be rejected, meaning the series is not stationary. On the other hand, if the p-value is less than $5 \%$, the null hypothesis is rejected, and the H1 hypothesis is accepted, the series is stationary (Kutlar, 2005). Looking at Table 1, probability values of LOGDP and LOODA variables are greater than $5 \%$ in level values; that is, variables are not stable at the level. After taking the first difference of these changes, the probability values p-value was less than 5\%; both variables became stationary at the first difference. For this reason, after the lag length is determined, a cointegration test is performed to examine whether these two variables act together in the long run. According to the test performed to determine the lag length in Table 2, it is seen that the appropriate lag length is one.

Table 2: Selection of Lag length

\begin{tabular}{lccllll}
\hline Lag & LogL & LR & FPE & AIC & SC & HQ \\
\hline 0 & -51.32241 & NA & 0.135567 & 3.677407 & 3.771704 & 3.706940 \\
1 & 4.379893 & $99.87998^{*}$ & $0.003839^{*}$ & $0.111732^{*}$ & $0.394620^{*}$ & $0.200329^{*}$ \\
2 & 7.129437 & 4.550970 & 0.004208 & 0.197970 & 0.669451 & 0.345632 \\
3 & 10.30826 & 4.823045 & 0.004509 & 0.254603 & 0.914676 & 0.461330 \\
4 & 12.86587 & 3.527732 & 0.005096 & 0.354078 & 1.202744 & 0.619870 \\
\hline
\end{tabular}

Note: The asterisk * indicates the appropriate delay number according to the relevant criteria.

A cointegration test can be performed in time series analysis after determining that the series have reached the first-order stationary and the number of lag is determined. In the Johansen cointegration test, dependent variable and independent variable separation in the model is not required. In Table 3, the analysis is made using the level values of the data in the Johansen cointegration test. 
Table 3: Johansen Cointegration Test Results

\begin{tabular}{|c|c|c|c|c|}
\hline Cointegration & Eigenvalue & Trace statisticsw & $5 \%$ critical value & Probability value \\
\hline None & 0.488424 & 22.19106 & 15.49471 & 0.0042 \\
\hline At most 1 & 0.044558 & 1.413013 & 3.841466 & 0.2346 \\
\hline \multicolumn{5}{|c|}{ Trace test indicates a cointegrated relationship of $5 \%$} \\
\hline \multicolumn{5}{|c|}{ Unconstrained cointegration Eigenvalue Rank Test (Eigenvalue) } \\
\hline None & 0.488424 & 20.77804 & 14.26460 & 0.0041 \\
\hline At most 1 & 0.044558 & 1.413013 & 3.841466 & 0.2346 \\
\hline
\end{tabular}

As a result of the Johansen cointegration test performed in Table 3, a cointegration relationship between these two variables was determined. In short, LOGDP and LOODA variables move together in the long run. If the existence of a cointegration relationship between variables is proved, a vector error correction model can be used. The vector error correction model is a VAR model arranged and constrained for the use of non-stationary variables that are cointegrated (Esen, 2007).

After the applied cointegration test, the Granger causality test based on the Vector error correction VEC model was conducted to reveal whether there is a causality relationship between these two variables. The error correction model applied in question automatically takes the first difference of both variables. The results of the Granger causality test based on the VEC model are shown in Table 4.

Tablo 4: Granger Causality Test Results

VEC Granger Causality/Block Exogeneity Wald Tests

Sample: 19862018

Included observations: 31

\begin{tabular}{lccc}
\hline Dependent Variables: LOGDP & & & \\
\hline Independent Variables & Chi-sq & Df & Possibility \\
\hline LOODA & 4.955918 & 1 & 0.0260 \\
All & 4.955918 & 1 & 0.0260 \\
\hline Dependent Variables: LOODA & & & \\
\hline Independent Variables & Chi-sq & Df & Possibility \\
\hline LOGDP & 0.004676 & 1 & 0.9455 \\
All & 0.004676 & 1 & 0.9455 \\
\hline
\end{tabular}

The results of the Granger causality test are decided according to the null hypothesis. If the null hypothesis is accepted, it implies that there is no causal relationship between these variables. On the other hand, if the null hypothesis is rejected, it indicates the existence of a causality relationship between these variables. Therefore, due to the Granger causality test, 
the null hypothesis was rejected because the probability value of the LOODA variable was lower than $0.05(0.0260)$, which is the significant level, that is, official development assistance (LOODA) is the cause of economic growth. However, since the probability value of the GDP variable is higher than the significant level of 0.05 (0.9455), the null hypothesis is accepted; that is, LOGDP is not the reason for official development assistance. After the Granger causality test based on the vector error correction model, the variance decomposition test is performed to look at the long and short-term changes of variables on each other. For this purpose, the results of the variance decomposition of the LOGDP and official development aid (LOODA) variables are shown in Table 5.

Table 5: Variance Decomposition of Variables in Model

\begin{tabular}{lllll}
\hline Period & LOGDP & LOODA & LOGDP & LOODA \\
\hline 1 & 100.0000 & 0.000000 & 8.101618 & 91.89838 \\
2 & 77.53423 & 22.46577 & 9.312326 & 90.68767 \\
3 & 68.98173 & 31.01827 & 10.44429 & 89.55571 \\
4 & 61.05541 & 38.94459 & 11.47237 & 88.52763 \\
5 & 55.01498 & 44.98502 & 12.39752 & 87.60248 \\
6 & 50.25751 & 49.74249 & 13.22414 & 86.77586 \\
7 & 46.50665 & 53.49335 & 13.95987 & 86.04013 \\
8 & 43.51286 & 56.48714 & 14.61350 & 85.38650 \\
9 & 41.09502 & 58.90498 & 15.19401 & 84.80599 \\
10 & 38.11841 & 60.88159 & 15.7099 & 84.29001 \\
\hline
\end{tabular}

When looking for LOGDP in the first period, a change in the LOGDP variable is entirely caused by itself. In other words, official development assistance does not affect. However, after the second period until the tenth period, the effect of official development assistance on the LOGDP variable gradually increases. Therefore, the effect of official development assistance on the LOGDP variable increases in the long run. Looking at the first period for the official development aid variable, $91 \%$ of the change in the official development assistance variable is caused by itself and $8 \%$ by LOGDP. However, the changes caused by the LOGDP continued with a slight increase after the first period until the tenth period. Therefore, it is seen from the test results that the effect of LOGDP on the official development aid variable in the short and long term is low. The results of variance decomposition are in line with the results of the causality test.

\section{Conclusion}

The flow of foreign aid to Afghanistan dates back to ancient times. However, to support the restructuring process that started in the country after establishing a new government in 2001, an intensive flow of foreign aid started. Since 2001, foreign aid has contributed significantly to Afghanistan's social and economic infrastructures, production, agriculture, 
education, health, and service sectors. At the same time, foreign aid made a notable contribution to areas such as increasing military power and strengthening democracy. Accordingly, the country's economy has grown by an average of 9\% per year between 20032012. However, after 2012, the decrease in official development assistance, the decrease in investments due to the increase of internal instability, the increase of drought, and the return of refugees had a negative effect on the macroeconomic indicators of the country. Thus, the country's economic growth rate has been growing at a low rate since 2012.

Despite billions of dollars in foreign aid flowing into Afghanistan and 3 trillion dollars worth of mines, the country still faces high poverty and unemployment. The lack of capacity in the Afghanistan administration has led to the deterioration of income distribution, widespread corruption, increased instability, and the inability to efficiently spend billions of dollars of aid. On the other hand, some of the foreign aid made to Afghanistan has been spent to realize the aims of the international countries, and some of the promised financial assistance has not been paid. The Afghanistan government focuses on extracting rich natural resources to free the country's economy from external dependency, accelerate economic growth, and reduce poverty and unemployment rates. For this reason, the government has introduced facilitating reforms in the mining sector to attract domestic and international investors.

In this study, the relationship between official development assistance and economic growth between 1986-2018 was analyzed using the time series method. In the analysis part of the study, ADF and PP unit root tests were first performed to stabilize the series. Since the official development assistance and economic growth series provide the first-degree stable condition, the cointegration test was conducted. As a result of the cointegration test, one cointegration relation was found between the series. Therefore, these two variables move together in the long run. Then, the Granger causality test based on the vector error correction model was conducted to determine the existence of a causality relationship between economic growth with the help of official development. As a result of the test, a one-sided causality relationship from official development assistance to economic growth was found. Accordingly, it has been concluded that official development assistance is the cause of economic growth. Finally, the result of the variance decomposition test indicates that the effects of official development assistance on economic growth, in the long run, are important. This result supports the result of the Granger causality test. As a result, increasing official development assistance for Afghanistan contributes to increasing the country's economic growth. 
Peer-review: Externally peer-reviewed.

Conflict of Interest: The author has no conflict of interest to declare.

Grant Support: The author declared that this study has received no financial support.

\section{References}

Ata, B., \& Eren, T. M. (2018). Dış ticaret-ekonomik büyüme ilişkisi: İran örneğinde bir nedensellik analizi. Ekonomik Teori ve Analiz Dergisi 2(4): 329-46.

Esen, E. (2007). Post Keynesyen istihdam analize ve Türkiye uygulaması, Ph.D. Thesis., PhD Thesis. Eskisehir, Anadolu Üniversitesi, Sosyal Bilimler Enstitüsü.

Fayissa, B. \& El-Kaissy, M.I. (1999). Foreign aid and economic growth developing countries : Further evidence. Studies in Comparative International Development.

Fasanya, İ., \& Onakoya, A. (2012). Does foreign aid accelerate economic growth? An empirical analysis for Nigeria. International Journal of Economics and Financial Issues, 2(4), 423-431.

Farahamand, M., \& Esen, E. (2018). Doğal kaynakların Afganistan ekonomisine katkısı, Journal of International Studies Sosyal Bilimler Bildiriler Kitab1, sayfa, 1114-1121. Kocaeli: İmascon.

Görgülü, M. (2016). Dış yardımların ekonomik büyüme üzerine etkileri. İnsan ve Toplum Bilimleri Araştırmaları Dergisi, 5(5), 1292-1322.

Gokmenoglu, K., Amin, M. Y., \& Taspinar, N. (2015). The relationship among international trade, financial development and economic growth: The case of Pakistan. Procedia Economics and Finance, 25, 489-496.

Hatemi-j, A., \& İrandoust, M. (2005). Foreign aid and economic growth: New evidence from panel cointegration. Journal Of Economic Development, 30(1), 71-80.

Hee Yiew, T., \& Lau, E. (2018). Does foreign aid contribute to or impeded economic growth?, 11(3), 21-30.

Hussen, M. S., \& Lee, K.W. (2018). Kye-Woo Lee. (2018). The impact of foreign aid on economic growth in Ethiopia. Asian International Studies Review 13(2): 87-112.

IEG. (2013). “Afghanistan: A Synthesis Paper of Lessons from Ten Years of Aid.”: 1-19. https://ieg.worldbankgroup. org/Data/reports/Afghanistan_Lessons_Ten_Years.pdf.

Karras, G. (2006). Foreign aid and long-run economic growth: Empirical evidence for panel of developing countries. Journal of International Development, 18, 15-28.

Kabil, T C. Büyükelçiliği Ticaret Müşavirliği, (2017), Afganistan Ülke Raporu.

Koç, B. (2016). Dış yardımların ekonnomik büyüme üzerine etkisi: Türkiye örneği. Kastamonu Üniversitesi İktisadi ve İdari Bilimler Fakültesi Dergisi(14), 145-156.

Kutlar, A. (2005). Uygulamall Ekonometri. Ankara: Nobel.

Levy, V. (1988). Aid and growth in sub-Saharan Africa: the recent experience. European Economic Review, 32 , 1777-1795. https://doi.org/10.1016/0014-2921(88)90085-2.

Liew, C. Y., Mohamed, M. R., \& Mzee, S.S. (2012). The impact of foreign aid on the economic growth of East African countries. Journal of Economics and Sustainable Development, 3, 129-138.

Mallik, G. (2008). Foreign aid and economic growth: A cointegration analysis of the six poorest African countries. Economic Analysis and Policy, 38(2), 251-260.

Mbah, S., \& Amassoma, D. (2014). The linkage between foreign aid and economic growth in Nigeria. International Journal of Economic Practices and Theories, 4(6), 2247-7225.

Nasery, J. (2014). Withdrawal, the economic shock to Afghanistan caused by aid reduction and troops. IEE Working Papers, No. 202, ISBN 978-3-927276-88-8. 
Noorani, J., \& Brouckere, L. (2016). A balancing act for extractive sector governance. Afghanistan Research and Evaluation Unit, publishing code, 1610E, ISBN 978-9936-628-15-1.

Papanek, G. (1973). Aid foreign private investment, savings, and growth in less developed countries.”, Journal of Political Economy, 1, 120-130.

Sekmen, F. (2006). Dış yardım ve ekonomik büyüme arasındaki karşılıklı ilişkinin eşbütünleşme ve Granger nedensellik testleri çerçevesinde incelenmesi: Mısır örneği. Ortadoğu Ylllığı 2006, 500-514.

Siddique, H., Kian, A., \& Batool, S. (2018). The impact of foreign aid on economic growth: evidence from a panel of selected countries. International Journal of Economics and Empirical Research, 34-37.

Tüzemen, S.,\& Barış Tüzemen, Ö. (2015). Dış yardımların ekonomik büyüme üzerine etkisi: Türkiye örneği. Kastamonu Üniversitesi İktisadi ve İdari Bilimler Fakültesi Dergisi, 8, 58-71.

United States Congress. (2018). "Special inspector general for Afghanistan reconstruction. https://www.sigar.mil/ pdf/quarterlyreports/Addendum_2018-01-30qr.pdf.

World Bank. (2017). Afghanistan development update. World Bank.

World Bank. (2018). "Afghanistan development update." World Bank Report.

World Bank. (December 2018). "Afghanistan development brief. Highlights of Afghanistan Fiscal Year 1398 Budget.

World Bank. (2019). Afghanistan Development Brief, World Bank.

Zazai, A. (2018). The impact of foreign aid on the economy, development, and stability of Afghanistan. MA in International Economics American University. 